\title{
Rumunsko-slovenské vzt’ahy v živote a tvorbe Gustáva Augustínyho
}

\author{
Patrik Šenkár (Komárno)
}

\begin{abstract}
Abstrakt
Príspevok poukazuje na životné osudy Gustáva Augustínyho, ktorý pôsobil ako novinár a publicista v poslednej tretine 19. storočia v rôznych mestách Dolnej zeme. Interpretačným spôsobom analyzuje jeho román Malý Pariž so špecifickým zretel'om na identifikáciu súdobých vztahov národností na báze interpretačných reflexií. Vyzdvihuje najdôležitejšie atribúty dobovej národnej a národnostnej existencie z aspektu Slovákov. Poukazuje na „Bukuriašt” ako na významný geografický a kultúrny stredobod. Zdôrazňuje potrebné zmierenie a spojenectvo medzi Slovákmi a Rumunmi. Beletrizovaný cestopis ako základný kameň „literárnej tvorby” Gustáva Augustínyho spolu s jeho (v náznakoch uvádzanými) publikačnými aktivitami poukazuje na relatívne komplexnú tvorivú osobnost' autora v pozadí jeho horlivosti za práva Slovákov. Konkrétne teoretické súvztažnosti sa konkretizujú adekvátnymi úryvkami z pôvodiny.
\end{abstract}

\section{Kl'účové slová}

Malý Pariž; Gustáv Augustíny; interpretácia; národnosti; spolunažívanie

\section{Abstract}

\section{The Romanian-Slovak Relations in the Life and Work of Gustáv Augustíny}

The contribution highlights the life of Gustáv Augustíny who has worked as a journalist and columnist in the last third of the 19th century in various cities of the Lowlands (Hungary). It analyzes his prose by means of interpretative method with specific regard to the identification of contemporary ethnic relations based on interpretive reflections. It highlights the most important attributes of contemporary national and ethnic aspect of the existence of the Slovaks. It refers to "Bukuriašt" as an important geographic and cultural centerpiece. It emphasizes the need of reconciliation and alliance between Slovaks and Romanians. Fictionalized prose as the cornerstone of Gustáv Augustíny's "literary work" along with him (in the stated indicated) publishing activity point to a relatively complex creative personality of the author behind his zeal for the rights of the Slovaks. Specifically, the theoretical correlations are gradually complemented by adequate excerpts from the original.

\section{Key words}

Little Paris; Gustáv Augustíny; interpretation; nationalities; coexistence

Štúdia sa zaoberá rumunsko-slovenskými vzt’ahmi v živote a tvorbe Gustáva Augustínyho. V kontexte času a miesta je významná aj jeho politická a najmä publicistická činnost'. Z dôvodu vymedzenej tematiky tejto práce sa však do zorného uhla nášho pohladu dostáva jeho beletrizovaná cestopisná práca o Bukurešti s názvom Malý Pariž. Uvádzaná novinárska činnost' však odzrkadl'uje Augustínyho postoje a tvorí určitý „odrazový mostík“ k jeho dielu Malý Pariž. 
„Spojenectvo medzi Slovákmi a Rumunmi - je nielen prirodzené, ale aj nutne potrebné, tým dôvernejšie, tým nerozlučnejšie, čím oba národy cítime, že malo byt’ už dávno uskutočnené. Rumuni a Slováci! Je pravda, že pôjdeme raz ruka v ruke?"1

V druhej polovici 19. storočia sa v slovenských dolnozemských osadách (nachádzajúcich sa aj na území súčasného Rumunska) hlásili k slovu osobnosti, ktorých činnosṫ a tvorba d’aleko presahovali úzky priestor vlastných pôsobísk. Jedným z nich bol aj Gustáv Augustíny (1851 - 1900), ktorého priekopnícke činy v slovensko-rumunskom zbližovaní, resp. úsilia o spoločné vystupovanie utláčaných nemad’arských národností duálneho Rakúsko-Uhorska boli a dodnes sú signifikantné. Jeho osoba je však z hladiska vývinu slovenskej prozaickej tvorby v Rumunsku „netypická“. Bol Slovákom, ale nepochádzal z radov Dolnozemcov a ani medzi nimi nežil. Napriek tomu ,... zohral dôležitú úlohu $v$ utužovani rumunsko-slovenských vztahov, teda ho možno pokladat za jedného z priekopnikov usúvztažñovania kultúr a komparatistického prístupu v kultúre $i$ presadzovania koncepcie, kultúrneho mostu' medzi národmi..."

Gustáv Augustíny sa narodil 31. 12. 1851 v Liptovskom Svätom Mikuláši. Po ukončení miestneho gymnázia študoval chémiu v Prahe. Po absolutóriu pracoval štyri roky ako praktikant v chrudimskom pivovare a rok ako chemik v Pivovarskom spolku. Z tohto obdobia je i jeho tlačená prvotina: brožúrka s názvom O lisovaném droždí, ktorá je vlastne odborného charakteru z aspektu jeho práce chemika. Počas svojho pražského pobytu sa zoznámil s Adolfom Heydukom, Rudolfom Pokorným, Antonínom Dvořákom či Jaroslavom Vlčkom. Tam sa stal aj členom Umeleckej besedy, kde prednášal o slovenskom básnikovi Samovi Chalupkovi. V roku 1881 sa zamestnal ako úradník v pražskej banke Slávia, kde však pracoval iba krátky čas, pretože ho vymenovali za reprezentanta banky v pobočkách v Martine a Budapešti. Počas svojho pražského pôsobenia sa však Augustíny nezdokonaluje iba v češtine, nemčine, francúzštine a ruštine (neskoršie ovládal aj mad’arčinu, srbčinu a rumunčinu) a v podvojnom účtovníctve, ale debutuje aj ako novinár v humoristicko-satirickom časopise Paleček. Koncom roku 1883 prišiel pracovne do Bukurešti, kde sa však nevedel stotožnit s miestnym prostredím. Začína písat články do Národných novín, no svoj iný (širšie koncipovaný) text s názvom Malý Pariž aj do Slovenských pohladov. Práve ten v nich vyšiel na pokračovanie v troch číslach piateho ročníka Slovenských pohladov (1885). Postupne sa začína už naplno venovat svojej novej profesii - novinárstvu. V Bukurešti pracoval pre noviny Universul a pre miestne francúzske periodiká L'Etoile roumaine a L'Expres-Orient; posielal články do Národných novín a pražských Národných listov. Celé toto obdobie novinárčenia bolo pre neho aj vynikajúcou politickou školou. V Sibiu sa Augustíny stáva redaktorom orgánu Rumunskej národnej strany v Sedmohradsku - časopisu Tribuna (1892). Nastupuje tam v januári roku 1893

1 ŠTEFANKO, Ondrej: Gustáv Augustíny - most medzi dvoma národmi. In: Malý Paríž. Nadlak: Vydavatelstvo Kultúrnej a vedeckej spoločnosti Ivana Krasku, 1997, s. 92.

2 O životných osudoch a „začlenení“ Gustáva Augustínyho do kontextu spomínaného vývinu bližšie pozri: ANOCA, Dagmar Mária: Slovenská literatúra v Rumunsku. Nadlak: Vydavatelstvo Ivan Krasko, 2010, s. 52. Tematicky podobne o ňom píse aj Matej Rádix vo svojom texte Dejiny nadlackých Slovákov. 
a jeho prvý článok s názvom Vocea unui slovac (Hlas jedného Slováka) bol uverejnený 27. januára s poznámkou redakcie: „Autor tohto článku, ktorý ho napisal rovno po rumunsky, je p. Gustav Augustiny, interný spolupracovnik redakcie Tribuny, sa podujal informovat' rumunskú verejnost' o zápasoch slovanských národov monarchie a oboznámit' vás s hlasmi týchto národov. "3 Ako redaktor ihned' začal oboznamovat Slovákov i Rumunov s národným hnutím oboch utláčaných národov.

Roky 1892 - 1896 boli rokmi vrcholných prejavov vzájomnosti uhorských národností. Po tomto období však nastáva postupný pokles dovtedy stúpajúcej tendencie spolupráce utláčaných národností Uhorska, a to aj medzi Rumunmi a Slovákmi. Augustíny odchádza zo Sibiu v roku 1897 pre rozpory, ktoré medzi ním a istými miestnymi kruhmi existovali už dlhší čas. Novinárska činnost̉ Gustáva Augustínyho (najmä v Sibiu) je nesmierne bohatá. V Tribune uverejňoval články najmä politického charakteru, ale i state o Jánovi Kollárovi, o slovenských trávniciach, o diele J. A. Komenského.

Dôležitým medzníkom nielen v živote národností Rakúsko-Uhorska, ale aj v osobnom živote Augustínyho bol kongres Rumunov, Slovákov a Srbov, ktorý sa uskutočnil v Budapešti (1895). Spojil národnostné politické strany Uhorska a položil základy ich spolupráce. Gustáv Augustíny, iniciátor kongresu, mal na ňom významnú úlohu: bol tlmočníkom, pretože jediný poznal jazyky všetkých prítomných národov. Aj na základe poznatkov z tejto akcie vyslovil dôležitú myšlienku o mierovom spolunažívaní: „Nech žije rumunský národ! Nech žije solidarita utláčaných národov! Nech žije rumunsko-slovenské bratstvo! " Neskôr sa vracia na Slovensko, ale už v septembri roku 1897 odchádza do Brašova. Spolupracoval vtedy ako redaktor s časopisom Slovenské listy, vydávanom v Ružomberku, ktorého šéfredaktorom bol Karel Salva; po siedmich číslach však tento časopis zanikol. Potom sa Augustíny rozhodol usadit v Budapešti, kde pracoval ako dopisovatel viacerých novín. Zamestnáva sa však aj v redakcii novín Tribuna poporul v Arade. Žiada stále, aby sa mohol vrátit na Slovensko, špeciálne do Martina. Martin ho však neprijíma.

Rumunsko-slovenská vzájomnosṫ sa (najmä počas jeho pôsobenia v Sibiu) začala u Augustínyho intenzívne prejavovat aj na školskom poli: viedli sa rokovania o sústavnom posielaní slovenských žiakov na rumunské a saské školy v Sedmohradsku. Všeobecné politicko-kultúrne ovzdušie, podopreté minimálnou mierou aj činnostou Augustínyho, spôsobilo, že sa vo vysokoškolských centrách (Budapešt, Viedeň, Praha) začínajú konat rumunsko-slovenské študentské večierky. Zo spolku slovenských študentov v Prahe (Detvan) mu posielajú list do Sibiu, v ktorom ho žiadajú o učebnice a čítanky rumunčiny, aby sa mohli učit reč národa, ktorý prejavuje tolké sympatie k Slovákom. Pri oceňovaní Augustínyho životného diela však nemožno obíst ani jeho podiel pri realizovaní rumunsko-slovenskej ženskej spolupráce (výučba Sloveniek po rumunsky, výmena ludových výšiviek, zhotovovanie krojov a pod.).

Ústrednou myšlienkou novinárskych postojov Gustáva Augustínyho je teda potreba spolupráce medzi utláčanými národnostami Uhorska, zápas o záchranu národnej svojbytnosti každého národa, potreba organizovania sa a snaha o zrovnoprávnenie.

3 Porov. pozn. 2, s. 92.

4 Tamtiež, s. 95. 
Vo svojich povzbudzujúcich článkoch v novinách objasnil niektoré významné otázky, týkajúce sa politických postojov národností. Vo vztahu k tomu (ale aj ku Slovákom či Rumunom) je príznačné uviesṫ dobový výrok, že „... Augustínyho duša uchvátila nás všstkých svojou neskonalou láskou $k$ Rumunom. Ako velmi nás l'úbil ten človek! Cudzi nášmu národu pokladal nás za lepšich, aki sme, a celý svoj život obetoval nám..." Tento významný človek, ktorý sa celý život usiloval o zblíženie Slovákov a Rumunov, v noci z 13. na 14. 2. 1900 spáchal samovraždu. ${ }^{6}$ Jeho úsilie však nebolo márne. Svedčí o tom i text, ktorý bol vyrytý na jeho náhrobnom kameni: „Vd’ačni Rumuni slovenskému bratovi. Postavili vd’ačni Slováci a Rumuni. Vd’ačná ti pamät’ v národe. "7

Najkomplexnejším prejavom Augustínyho osobnosti je však práca Malý Paríz: v nej sa prejavili aj jeho literárne vlohy. Nazrel v nej aj pod povrch javov, zaregistroval dobovú atmosféru, využívajúc nemilosrdnú iróniu a uštipačné poznámky. Augustínyho Malý Paríz treba hodnotit ako prvý komplexný obraz, aký sa slovenskému čitatel'ovi v Rumunsku o Bukurešti predostrel.

Gustáv Augustíny vo svojom prozaickom diele Malý Paríž, ktorý tvorí vlastne prechod od vecnej literatúry k beletrii, uvádza historický vývin mesta Bukurešt od 14. storočia. ${ }^{8}$ Podáva romantické i menej romantické povesti o vzniku tohto mesta. Jeho etymologické

5 Tamtiež, s. 101. Sú to slová rumunského politika Vasileho Goldişa (1862 - 1934), člena rumunskej akadémie, po ktorom je v súčasnosti pomenovaná Západná univerzita v Arade.

6 O „pohnutom“ osude Gustáva Augustínyho (styky s českou inteligenciou, štvormesačné väznenie, úmorná práca úradníka) píše aj Peter Andruška. Prízvukuje fakt, že Augustíny ovládal sedem jazykov „utláčaných národností Rakúsko-Uhorska“. Vyzdvihuje jeho evidentný názor o potrebe spolupráce medzi národnostami a myšlienku, podla ktorej „osud svojho národa mu je ideálom“. Hlbšie analyzuje jeho novinársku prácu v Bukurešti (Universul), Sibiu (Tribuna), Arade (Tribuna poporului) či Ružomberku (Slovenské listy), čím jeho osobnost' hodnotí ako kvalitného novinára. O životnej ceste Gustáva Augustínyho bližšie pozri: ANDRUŠKA, Peter: Súčasni slovenski spisovatelia z Rumunska. Nitra: Univerzita Konštantína Filozofa v Nitre, 2009, s. 38 - 41; ŠTEFANKO, Ondrej: Gustáv Augustíny - most medzi dvoma národmi. In: Ponachodené súvislosti. Nadlak: Vydavatel'stvo Ivan Krasko, 2004, s. 45 - 56; ŠTEFANKO, Ondrej: Gustáv Augustíny - most medzi dvoma národmi. In: ANOCA, Dagmar Mária - BARBORICĂ, Corneliu - ŠTEFANKO, Ondrej (eds.): Variácie 8. Bukurešt: vyd. Kriterion, 1986, s. 148 - 157; ŠTEFANKO, Ondrej: Gustáv Augustíny - most medzi dvoma národmi (rovnomenný doslov ku knihe Malý Paríz). In: Malý Paríž. Nadlak: Vydavatel'stvo Kultúrnej a vedeckej spoločnosti Ivana Krasku, 1997, s. 89 - 104, resp. ŠTEFANKO, Ondrej: Gustáv Augustíny - most medzi dvoma národmi. In: Pohladaj korene svoje. Nadlak: Vydavatel'stvo Kultúrnej a vedeckej spoločnosti Ivana Krasku, 1998, s. 163 - 179. Jeho osobu a (najmä publicisticko-politickú) činnost' uvádza i v súvislosti s osobou Gustáva Maršalla-Petrovského aj Peter Andruška. O tom bližšie pozri: ANDRUŠKA, Peter: Dolnozemské podoby slovenskej kultúry. Nitra: Univerzita Konštantína Filozofa v Nitre, 2007, s. 117 - 118 . O spomínanom Kongrese Rumunov, Slovákov a Srbov roku 1895 pozri rovnomenný článok Milana Krajčoviča. In: Dolnozemský Slovák I (XVI), 1996, č. 1, s. 11 - 13.

7 Porov. pozn. 6, s. 101. V súčasnosti ani hrob, ani pamätná tabula Gustáva Augustínyho sa nezachovali (bol pochovaný v Arade).

8 Po prvom uverejnení tohto diela v Slovenských pohladoch (1885) jeho reedícia vyšla až v roku 1997. O tom bližšie pozri: AUGUSTÍNY, Gustáv: Malý Pariž. Nadlak: Vydavatel'stvo Kultúrnej a vedeckej spoločnosti Ivana Krasku, 1997. Týmto vydavatel'ským činom Ondrej Štefanko ako zodpovedný redaktor „ilustroval vlastne svoju koncepciu ,kultúrneho mostu“ bilingválnych (bikultúrnych) jedincov... a zároveň sa pokúsil aj o syntézu otázok slovensko-rumunských a rumunsko-slovenských vztahov..." In: ANOCA, Dagmar Mária: Slovenská literatúra v Rumunsku. Nadlak: Vydavatel'stvo Ivan Krasko, 2010, s. 173. Samotný text (vo výbere Ondreja Štefanka) bol publikovaný aj v zborníku Variácie 8. O tom bližšie pozri: AUGUSTÍNY, Gustáv: Malý Pariž. In: ANOCA, Dagmar Mária - BARBORICĂ, Corneliu - ŠTEFANKO, Ondrej (eds.): Variácie 8. Bukurešt: vyd. Kriterion, 1986, s. 158 - 178. 
vysvetlenia sa často prikláňajú $\mathrm{k}$ tým bájnejším variantom (Bukurešt - mesto radosti). Hovorí o dôležitosti vtedajšieho „Bukuriaštu“ i celého okolia. Tento historický lineárny proces sa dostáva až do autorovej súčasnosti, ked’ vyzdvihuje progres mesta. Približuje mentalitu a kultúru obyvatelov hlavného mesta, vychádzajúc zo spolupráce a sympatie medzi národnými hnutiami. Na druhej strane však prízvukuje jeho pomernú mladost', chudobu na dejinné zjavy či historické pamiatky. Podáva stručný obraz osudu rumunského národa a stratifikáciu mestskej spoločnosti na základe majetku. Kriticky sa vyjadruje najmä o absencii tzv. stredného stavu, ktorý by najviac vedel povzniest́ tvorivé dianie v meste. Vyslovuje sa za to, že: „Škoda v skutku dat’ zahynút každej pamiatke na život ten kultúrny, nám teraz divným sa zdajúci, ale pre vývin národný predsa velmi pamätihodný."9 Autor však hovorí aj o potrebe nástupu nového životného spôsobu, samozrejme, so zachovaným „maloparížskym fazónom“. Táto originalita sa vysvetluje počtom ulíc, opisom domov, dvorov, záhrad, chalúp, kolíb. Bukurešt prirovnáva k velkej záhrade, v ktorej sa strácajú príbytky pánov. Je to znak toho, že súdobé mesto sa viac-menej konsoliduje vo vztahu k vyššej a nižšej spoločenskej vrstve. Na základe toho je zrejmé, že „... mesto je rozdelené na rozličné spoločnosti, podobné malým republikám, ktoré majú svoje zákony, svoje zvyky, svoj žargón a vychytené výrazy. " ${ }^{10}$ Mimoriadny dôraz sa v texte kladie aj na opis stavieb kostolov, resp. zaniknutých kláštorov: prízvukuje sa pri nich spätost̉ národa (rumunského i slovenského) so samotným náboženstvom (katolícky, evanjelický, kalvínsky, arménsky kostol, resp. židovská synagóga). Augustíny uvádza aj zvyky jednotlivých cirkví, ktoré pre „cudzinca“ môžu byt nezvyčajné (napríklad klopanie na volne zavesenú dosku - akoby zvonenie a pod.). Odzrkadluje sa tu binárna opozícia „my - oni“, teda rumunské a slovenské. Nie je však medzi nimi antagonistická hranica. Práve v tomto vztahu je Augustíny určitým mostom, spájajúcim oba národy.

Z čisto historického aspektu autor postupne prechádza k otázkam vývinu jazyka (ktorý konkretizuje aj príkladmi: napríklad spoločné slová, vztahujúce sa na pastiersky život) a k opisu niektorých etnologických obyčajov (deň Troch králov, sobáše, pohreby). Zo sociálneho aspektu sa v texte špeciálne uvádza existencia špitálov, sirotincov a vyšších dievčenských škôl, ktoré tvoria pendant v opozícií „cirkevné - svetské“. Ich stav je v súdobom Malom Parízi adekvátny, slúžiaci na zlepšenie zdravotného i výchovného stavu obyvatelstva.

Augustíny vcelku detailne opisuje aj svetské pamätihodnosti hlavného mesta: univerzitu, botanickú záhradu, národné divadlo, královský palác, ale aj „fiakre-birže, tramwaje, omnibusy“ - lebo aj tie „patria k pamätihodnostiam“. Pri univerzite uvádza systém školstva, charakteristiku štyroch fakúlt, počet poslucháčov, ale aj to, že napriek vysokej úrovni poskytovaného vzdelania väčší počet mládeže študuje v Paríži, Berlíne či Viedni. Kriticky sa vyjadruje aj o dezolátnom stave botanickej záhrady (primitívne zariadenie, ošarpaný nízky plot). Vyzdvihuje však pompéznost̉ a ozdobnost̉ národného divadla a jeho podobnost’ s milánskou La Scalou. Pri tejto otázke sa však vyslovuje za čím častejšie používanie rumunčiny v rámci dramatických i operných predstavení. Podobne je „útulkom krásy

9 AUGUSTÍNY, Gustáv: Malý Pariž. Nadlak: Vydavatelstvo Kultúrnej a vedeckej spoločnosti Ivana Krasku, 1997, s. 12. 
a úluby“ královský palác s krásnym čínskym salónom. Vzápätí sa ako empatický skutok javí to, že král’ovná v spoločenskom styku s královským palácom uviedla národný kroj ako odporúčané oblečenie v rámci dobročinných plesov. Tieto kroje Augustíny konfrontuje z národnostného hladiska a dospieva k záveru, že rumunský ženský kroj je rozmanitejší a krajší než slovenský, ale v prípade mužského „my - Slováci“ vynikáme.

Autor prízvukuje rýchle kroky meniacej sa tváre mesta, ktorého znakom je Bulevard, ktorý prirovnáva k peštianskej Andrássyho triede. Ten, podobne s Grand Hotelom, by svojou eleganciou mal dôstojne reprezentovat Malý Paríž. V rámci tejto problematiky sa dotýka aj nepravidelnosti bukureštských ulíc a metamorfózy ich názvov; uvádza sústredenosṫ verejného života (šum, pestrost', lesk, pohyb).

Zaujímavým aspektom je uvádzanie tematiky módy, ktorá tiež charakterizuje vtedajšiu Bukurešt: šaty, klobúky, látky a ich nosenie „Maloparížankami“. Augustíny konštatuje, že tieto ženy hlavného mesta sa viac-menej približujú z tohto pohladu „Vel'koparížankám“.

Zaujímavou črtou je rozvíjanie otázky kníhkupectiev: je velavravné, že až 80 \% kníh pochádza z oblasti francúzskej literatúry. Je to „... najlep̌̌́ dôkaz o intelektuálnych vztahoch medzi Parižom na Seine a Malým Parižom nad Dîmbovicou. "11 Augustíny však kritizuje slabo vyvinutú rumunskú literatúru a evidentné francúzofilstvo, týkajúce sa prevažne beletrie. Naopak, domácu žurnalistiku pokladá za značne perspektívnu.

V susedstve týchto kníhkupectiev sú aj rôzne obchody, ktoré sú však najmä v rukách cudzincov. Ich vývoj vidí v spätosti s existenciou železnice i riadnych ciest, ktoré nesú v sebe základné podmienky pri výmene tovaru.

Autor sa vyslovuje aj za zachovanie dôstojnosti každého obyvatela, nezávisle na jeho národnosti, resp. náboženskom presvedčení, ved' „... slniečko svieti na všetkých rovnako a oko Vševidiace hladi práve tak spravodlive v Malom ako Vel'kom Pariži, rovnako vidi právo $i$ krivdu páchanú na jednotlivcoch $i$ národoch. " 12

Dôležitým faktorom pre cudzinca je opis hotelierstva a gastronómie mesta. Autor sa kladne vyslovuje k tejto problematike, avšak uvádza značný rozdiel medzi francúzskym a rumunským hostincom. Opät uvádza „rozvrstvenie“ týchto zariadení: hotely, reštaurácie so záhradami, reštaurácie bez záhrad, kaviarne, cukrárne. Konštatuje zaujímavý fakt, že prvú „... elegantnú reštauráciu ešte dávno pred uvedením hotelov zariadil tu Slovák Hrčka z Liptovského Ružomberku, emigrant po boji ,za mad'arskú slobodu‘..."13 Na základe tejto skutočnosti uvádza existenciu umeleckých zážitkov (hudby, tanca, spevu) v rámci týchto zariadení. Vyzdvihuje však nedostatok kvalitnej a dobrej hudby, ktorú reprezentujú najmä cigánski „lautári“, najsúcejší a najprirodzenejší interpreti národnej hudby. Augustíny sa na širšej ploche venuje aj problematike národných piesní, kritizuje ich absenciu; uvádza však aj ich delenie (epické i lyrické piesne do tanca i colinde - koledy), ktoré sú podkladom pri opise typov tancov. Tieto marginálie o spoločenskom živote dostávajú konkrétny výraz a význam najmä pri verejných slávnostiach a zábavách, ktoré môžu byt okorenené aj (dobovo vychytenou) športovou činnostou.

11 Porov. pozn. 10, s. 33.

12 Tamtiež, s. 37.

13 Tamtiež, s. 41. 
Zaujímavým aspektom je teda (už spomínané) rozšírenie používania francúzštiny a jej kontaminácia na úkor čistoty vlastnej reči. Autor uvádza aj jej prítomnost̉ v školskom vzdelávacom systéme. Prízvukuje však fakt, že: „... Rumuni snažia sa svoju reč očistit’ od cudzoty a že chcú slová $i$ výrazy prebrané $z$ iných reč nahradit novými, z matky-reči latiny..." ${ }^{14}$ Poukazuje však na zhubný vplyv bezohladného neologizovania a hovorí o racionálnej potrebe zachovania si jazykových tradícií. Súdobý rumunský národ pokladá za demokratický, štátne zriadenie - královstvo - za dostačujúce, spoločenské rozvrstvenie za adekvátne. Znakom tejto liberálnosti je aj napríklad možnost' účasti všetkých spoločenských vrstiev na plesoch pri dodržiavaní správneho oblečenia; možnosť usporadúvania elegantných zábav aj vo vlastných domoch a pod.

Autor teda vo všeobecnosti, ale i konkrétne podáva „... obraz dnešného stavu, krátky opis o predošlosti národa, tvoriaceho dnes štát rumunský, hlavne pre slovanskost’ jeho bývalých ustanovizni. "15 Vidíme v tom jeho snahu o určitú klenbu medzi rumunským a slovenským, teda jeho určité sprostredkovanie medzi národmi a národnostami. Tie sa o. i. opisujú pri charakteristike pomerov (dejepisných prameňov), ktoré detailnejšie uvádza v časovom rozmedzí do roku 1830 a po roku 1859. Uvádza práva a povinnosti rumunských kniežat či panovníkov, volbu vojvodu. Charakteristickým znakom toho, že „... Rumuni žili so Slovanmi v úzkom spojeni..."16 je aj zaujímavý fakt, že „... asi do roku $1679 \ldots$ začinajú sa osnovat'v rumunčine, ale $i$ vtedy titul vojvodov na začiatku každého dekrétu zostáva ešte vždy slovanský. " 17

Autor uvádza politický a hospodársky opis hlavného mesta ako centra celej krajiny, ktorá „... je v pravom zmysle slova zemou požehnanou; úrodnost' jeho pôdy vyrovná sa v rovinatých polohách úplne Banátu..." ${ }^{18} \mathrm{Z}$ tohto pohladu uvádza prítomnost̉ najvýznamnejších polnohospodárskych plodín (pšenica, kukurica, žito, jačmeň, ovos), povestnost̉ starodávneho včelárstva, chov dobytka, vel'kú rozlohu hôr, množstvo minerálov a bohatost petrolejových prameňov. Na druhej strane však prízvukuje celkovú absenciu rumunského domáceho priemyslu, resp. väčší dovoz než vývoz. Podobne sa stavia aj k otázke ozbrojovania sa, v ktorom sú vydané sumy na vojsko ohromné. Napriek tomu vyzdvihuje dôležitost̉ Rumunska, nakolko ho svet prirad'uje „... v rade štátov europských na 13. miesto; dôležitost' jeho bude rást č́m d’alej tým viac..." ${ }^{19}$

Na základe týchto analýz života i diela Gustáva Augustínyho je zrejmé, že tak ako v minulosti, aj v súčasnosti je vel'mi dôležité zaujímat̉ sa o iné národnosti, a tým pomáhat lepšiemu spolunažívaniu.

\footnotetext{
14 Tamtiež, s. 50.

15 Tamtiež, s. 63.

16 Tamtiež, s. 80.

17 Tamtiež, s. 77 - 78.

18 Tamtiež, s. 58.

19 Tamtiež, s. 63.
} 


\section{Literatúra}

ANDRUŠKA, Peter: Do Nadlaku i do sveta. In: Súčasní slovenskí spisovatelia z Rumunska. Nitra: Univerzita Konštantína Filozofa v Nitre, 2009, s. 45 - 56.

ANDRUŠKA, Peter: Historik slovenskej Dolnej zeme. In: Dolnozemské podoby slovenskej kultúry. Nitra: Univerzita Konštantína Filozofa v Nitre, 2007, s. 181 - 212.

ANOCA, Dagmar Mária: Literatúra v medzivojnovom obdobi (1918 - 1945). In: Slovenská literatúra v Rumunsku. Nadlak: Vydavatel'stvo Ivan Krasko, 2010, s. 55 - 66.

ANOCA, Dagmar Mária: Slovenská literatúra v Rumunsku. Nadlak: Vydavatel’stvo Ivan Krasko, 2010. AUGUSTÍNY, Gustáv: Malý Pariž. In: ANOCA, Dagmar Mária - BARBORICĂ, Corneliu - ŠTEFANKO, Ondrej (eds.): Variácie 8. Bukurešt: vyd. Kriterion, 1986, s. 158 - 178.

AUGUSTÍNY, Gustáv: Malý Pariž. Nadlak: Vydavatel'stvo Kultúrnej a vedeckej spoločnosti Ivana Krasku, 1997.

BRUYÉRE, Jean de La: Charaktery. Bratislava: Slovenský spisovatel', 1987.

KRAJČOVIČ, Milan: Kongres Rumunov, Slovákov a Srbov roku 1895. In: Dolnozemský Slovák I (XVI), 1996, č. 1, s. 11 - 13.

ŠTEFANKO, Ondrej: Gustáv Augustíny - most medzi dvoma národmi. In: ANOCA, Dagmar Mária BARBORICĂ, Corneliu - ŠTEFANKO, Ondrej (eds.): Variácie 8. Bukurešt: vyd. Kriterion, 1986, s. $148-157$.

ŠTEFANKO, Ondrej: Gustáv Augustiny - most medzi dvoma národmi. In: Malý Paríž. Nadlak: Vydavatel’stvo Kultúrnej a vedeckej spoločnosti Ivana Krasku, 1997, s. 89 - 104.

ŠTEFANKO, Ondrej: Gustáv Augustíny - most medzi dvoma národmi. In: Pohladaj korene svoje. Nadlak: Vydavatel'stvo Kultúrnej a vedeckej spoločnosti Ivana Krasku, 1998, s. 163 - 179.

ŠTEFANKO, Ondrej: Gustáv Augustiny - most medzi dvoma národmi. In: Ponachodené súvislosti. Nadlak: Vydavatel'stvo Ivan Krasko, 2004, s. 45 - 56.

\section{doc. PaedDr. Patrik Šenkár, PhD.}

Katedra slovenského jazyka a literatúry

Pedagogická fakulta, Univerzita J. Selyeho

Bratislavská cesta 3322, 94501 Komárno, Slovensko

senkarp@ujs.sk 